\title{
ESTIMASI DOSIS RADIASI PERMUKAAN KULIT PADA PEMERIKSAAN RADIOLOGI DENGAN APLIKASI AHD RAD BERBASIS WEB
}

\author{
Sudibyo Dwi Saputro'), Arif Fahmi'2), I Wayan Ari Makmur ${ }^{3)}$, Nurul Qomariyah4) \\ 1)Instalasi Radiologi, Rumah Sakit dr Soedjono, Magelang, Provinsi Jawa tengah, Indonesia \\ ${ }^{2)}$ Bidang Penunjang, Rumah Sakit Umum Daerah Provinsi NTB, Mataram, Indonesia \\ 3)Instalasi Radioterapi, Rumah Sakit Umum Daerah Provinsi NTB, Mataram, Indonesia \\ ${ }^{4)}$ Program Studi Fisika, FMIPA,Universitas Mataram, Mataram, Indonesia \\ Corresponding author : Sudibyo Dwi Saputro \\ E-mail : sudibyorsumgl@gmail.com
}

Diterima 02 September 2021, Disetujui 01 Oktober 2021

\begin{abstract}
ABSTRAK
Dosis radiasi Sinar-X pada pemeriksaan radiologi dihitung berdasarkan dosis permukaan kulit yang diterima pasien. Hal tersebut dilakukan sebagai evaluasi terhadap pemberian dosis radiasi. Penelitian ini bertujuan untuk mengembangkan sistem aplikasi berbasis web dalam menghitung estimasi dosis radiasi permukaan kulit pasien yang diberi nama AHD Rad. Metode penelitian dilakukan dengan desain rancangan pengembangan, dan pengambilan data berupa nilai faktor eksposi. Dilakukan uji komparasi dosis radiasi antara AHD Rad dan software CALDose_X versi 5.0. Perhitungan dosis radiasi pada AHD Rad menggunakan pendekatan matematis dan fisika merujuk kepada Technical Report Series International Atomic Energy Agency (TRS IAEA) 457 tahun 2007. Data nilai faktor eksposi dengan parameter tegangan tabung $(\mathrm{kV})$, arus tabung (mAs) dan jarak tabung ke film (FFD) yang sama, di masukkan melalui aplikasi CALDose_X versi 5.0 dan AHD Rad. Jumlah data sebanyak 50 dengan pengambilan data secara random sampling pada pemeriksaan radiografi umum. Pengolahan data menggunaan SPSS 11. Uji komparasi dilakukan dengan margin error $5 \%$ dengan tingkat kepercayaan $95 \%$. Hasil menunjukkan nilai tidak terdapat perbedaan signifikan pada uji komparasi yang dilakukan pada aplikasi AHD Rad dengan CALDose_X versi 5.0. Sehingga aplikasi AHD Rad dapat dipergunakan dalam estimasi dosis radiasi pasien.
\end{abstract}

Kata kunci: Dosimetri; Dosis Radiasi Permukaan Kulit; AHD Rad

\begin{abstract}
$X$-ray radiation dose in a radiological examination is calculated based on the skin surface dose received by the patient. This is done as an evaluation of the radiation dose. This study aims to develop a webbased application system for calculating the estimated dose of radiation to the patient's skin surface, which is named AHD Rad. The research method was carried out with a development design and data collection in exposure factor values. A comparative test of radiation dose was conducted between AHD Rad and CALDose_X software version 5.0. Calculation of radiation dose on AHD Rad using mathematical and physical approaches refers to the Technical Report Series International Atomic Energy Agency (TRS IAEA) 457 in 2007. Exposure factor value data with tube voltage parameters (kV), tube current (mAs), and tube distance to film (FFD), entered through the CALDose_X application version 5.0 and AHD Rad. The number of data is 50 by taking data by random sampling on general radiographic examination. Data processing using SPSS 11. The comparison test was carried out with a margin of error of $5 \%$ with a $95 \%$ confidence level. The results show no significant difference in the comparison test carried out on the AHD Rad application with CALDose_X version 5.0 so that the AHD Rad application can be used to estimate the patient's radiation dose.
\end{abstract}

Keywords: Dosimetry; Skin Surface Radiation Dose; AHD Rad.

\section{PENDAHULUAN}

Sinar-X bermanfaat untuk menghasilkan gambar yang dipergunakan dalam penegakan diagnosa medis, namun juga menyimpan potensi efek negatif yang dapat ditimbulkan (Dianasari \& Koesyanto, 2017). Sinar-X merupakan jenis radiasi pengion, dapat memberikan efek berupa kerusakan sel melalui terbentuknya ion radikal bebas memicu terjadinya mutasi DNA atau sel (Dianasari \& Koesyanto, 2017)(Jones et al., 2012). Mutasi DNA atau sel, merupakan awal terbentuknya kelainan pada jaringan organ dan berpotensi memunculkan penyakit seperti kanker. Oleh karena itu perlunya penerapan prinsip optimasi dalam memberikan dosis radiasi medis kepada 
pasien untuk menghindari potensi munculnya efek negatif.

Dasar hukum atau rujukan yang dijadikan landasan pentingnya memperhatikan dosis radiasi pasien adalah Peraturan Pemerintah No 33 tahun 2007 tentang Keselamatan Radiasi Pengion Dan Keamanan Sumber Radioaktif pasal 33 ayat 2 menjelaskan bahwa "Setiap pekerja, pasien, pendamping pasien, dan/atau orang lain yang berhubungan dengan radiasi wajib memakai pemantau dosis perorangan dan peralatan protektif Radiasi sebagaimana dimaksud dalam Pasal 31 ayat (2) huruf b dan huruf d" (UndangUndang No. 33 Tahun 2007 Tentang Keselamatan Radiasi Pengion Dan Keamanan Sumber Radioaktif, 2007). Secara jelas termaktub bahwa pasien memakai pemantau dosis perorangan dalam hal ini harus teridentifikasi berapa dosis yang diterima oleh pasien. Sejalan dengan Standar Penilaian akreditasi rumah sakit versi SNARS pada Asessmen Pasien (AP 6.3.1) bahwa salah satu penilaian dalam akreditasi rumah sakit adalah identifikasi maksimum dosis radiasi pasien (KARS, 2017). Sedangkan nilai tingkatan dosis maksimum dosis radiasi pasien permukaan kulit dituangkan dalam pedoman DRL Bapeten.

Estimasi dosis pasien dapat diidentifikasi menggunakan DAP atau KAP. Dose Area Product (DAP) adalah kuantitas yang digunakan dalam menilai risiko radiasi dari prosedur pemeriksaan sinar- $X$ diagnostik dan intervensional. Ini didefinisikan sebagai dosis yang diserap dikalikan dengan area yang disinari, dinyatakan dalam satuan $\mathrm{Gy} \cdot \mathrm{cm}^{2}$. Sedangkan Kerma Area Product (KAP) adalah bagian integral dari kerma udara bebas di atas luas berkas sinar-x pada bidang yang tegak lurus terhadap sumbu berkas, dimana untuk semua tujuan proteksi radiasi praktis KAP disetarakan dengan DAP(Kim et al., 2009). Selain itu, pada modalitas intervensional umumnya sudah dilengkapi dengan indikator dosis pada layar monitor konsol berupa laju kerma udara atau KAP atau peak skin dose. Indikator tersebut dapat digunakan untuk mengidentifikasi perkiraan dosis pasien. Jika belum ada fitur indikator dosis, maka dapat menggunakan data keluaran radiasi (radiation output) dari hasil uji kesesuaian atau uji kalibrasi didukung dengan parameter eksposi (kondisi penyinaran) kV, mAs, Focus Film Distance (FFD), Focus Skin Distance (FSD), dan Luasan bidang sinar-X pada citra (Bapeten, 2019).

Sejalan dengan BAPETEN bahwa dosimetri pasien dapat dilakukan secara langsung atau tidak langsung. Pengukuran secara langsung dilakukan dengan menggunakan alat TLD (thermoluminescent dosimeter) yang membutuhkan biaya dan anggaran besar dalam penggunaannya. Sedangkan metode pengukuran tidak langsung dilakukan dengan melakukan pendekatan matematis fisika dalam pengukurannya. Metode pengukuran secara langsung dan tidak langsung dijelaskan dalam Technical Report Series International Atomic Energy Agency (International Atomic Energy Agency, 2007).

Dosimetri radiasi menjadi area penting sebagai bagian dari instalasi radiologi, formulasi dan prosedur pengukuran untuk dosimetri radiologi yang distandarisasi melalui kode praktik internasional yang menjelaskan metodologi yang diperlukan dengan pengukuran kerma udara dari perangkat sinar$X$ dalam kondisi yang ditentukan (PetoussiHenss et al., 1998). Pentingnya pengukuran dan pendokumentasian dosis radiasi menjadi latar belakang dibangunnya aplikasi AHD Rad yang diintegrasikan dengan SIM RS serta menggunakan metodologi internasional IAEA TRS 457 melalui perhitungan kerma udara dan perhitungan fisika matematis. Selain itu kelebihan dari AHD Rad yang telah terhubung dengan server RS, adalah identitas pasien berupa nomor RM, nama, tangal lahir, alamat menjadi sinkron dan dapat terhindar dari pengulangan pengetikan identitas pasien dan mengurangi kesalahan pengetikan. Selain itu pelaporan dan rekam dosis pasien dapat dengan mudah diakses, termasuk menggunakan android.

Sebagai bahan referensi dan pembanding, penulis menggunakan komparasi dengan hasil perhitungan dosimetri menggunakan CALDose_ $X$ versi 5.0. CALDose_X versi 5.0 adalah software yang dibuat oleh ilmuwan asal Brazil, Richard Kramer, dkk dan sejak tahun 2008 telah digunakan untuk memperkirakan dosis serap pada organ dan jaringan lunak, dosis efektif dan risiko kanker akibat penyinaran sinar-X pada pemeriksaan radiodiagnostik tertentu (Meghzifene et al., 2010).

\section{METODE PENELITIAN}

Penelitian ini adalah dengan membuat aplikasi komputer berbasis web yang terintegasi dengan SIM RS, untuk menghitung estimasi dosis radiasi permukaan pasien pada pemeriksaan radiologi. Formulasi dan prosedur pemeriksaan dilakukan berdasarkan kode praktik internasional dosimetri IAEA TRS 457. Teknik pengumpulan data dilakukan dengan mengumpulkan data variasi faktor eksposi berupa nilai tegangan tabung $(\mathrm{kV})$, arus tabung (mAs), dan jarak tabung ke pasien (FFD). Data kuantitatif yang diperoleh berupa informasi data 
variasi nilai faktor eksposi pada beberapa jenis pemeriksaan. Selanjutnya nilai faktor eksposi tersebut dimasukan ke dalam aplikasi AHD Rad dan CALDose_X versi 5.0.

Secara matematis, perhitungan dosis radiasi AHD Rad, sebagai berikut(Bapeten, 2019) :

$\mathrm{Ke}=\mathrm{Ki} \times \mathrm{BSF}$

$\mathrm{Ke}=$ entrance surface air kerma

$\mathrm{Ki}=$ incident air kerma

BSF = backscater factor

Sedangkan nilai Ki diperoleh dari

$$
\begin{aligned}
& K i=Y(d) P_{I t}\left(\frac{d}{d_{F T D}-t p}\right) \\
& \mathrm{FSD}=\mathrm{dFTD}-\mathrm{tp}
\end{aligned}
$$

Dari persamaan (2) dan (3) didapatkan

$$
K i=Y(d) P_{I t}\left(\frac{d}{F S D}\right)
$$

$$
\begin{aligned}
& \text { Dengan } Y(d)=\text { keluaran sinar- } X \text { dari } \\
& \mathrm{d}=\text { jarak pengukuran } \\
& \mathrm{P}_{\mathrm{lt}} \quad=\text { faktor eksposi tabung } \\
& \mathrm{d}_{\mathrm{FTD}}=\text { jarak fokus tabung ke }
\end{aligned}
$$

Tabel 1. Data Penelitian Pada Jenis Pemeriksaan Radiologi AHD Rad

\begin{tabular}{cllcc}
\hline $\begin{array}{c}\mathbf{N} \\
\mathbf{0}\end{array}$ & $\begin{array}{l}\text { Pemerik } \\
\text { saan }\end{array}$ & $\begin{array}{l}\text { Proyek } \\
\text { si }\end{array}$ & FSD & $\begin{array}{l}\text { Ukuran } \\
\text { Kolimasi }\end{array}$ \\
\hline 1 & Thorax & & 160 & $35 \times 35$ \\
\hline 2 & Thorax & LAT & 150 & $35 \times 43$ \\
\hline 3 & Abdomen & AP/PA & 80 & $35 \times 43$ \\
\hline 4 & Shoulder & AP & 75 & $18 \times 24$ \\
\hline 5 & Cranium & AP/PA & 80 & $24 \times 30$ \\
\hline 6 & Femur & AP & 75 & $25 \times 43$ \\
\hline 7 & Lumbal & AP/PA & 70 & $25 \times 43$ \\
\hline 8 & Pelvis & AP/PA & 80 & $35 \times 43$ \\
\hline 9 & Thorakal & AP/PA & 80 & $25 \times 43$ \\
\hline 10 & Sacrum & AP/PA & 80 & $18 \times 24$ \\
\hline 11 & Clavicula & AP & 75 & $18 \times 24$ \\
\hline 12 & Cervical & AP/PA & 80 & $18 \times 24$ \\
\hline 13 & Colon & AP/PA & 75 & $35 \times 43$ \\
& inloop & & & \\
\hline 14 & Humerus & AP & 75 & $24 \times 30$ \\
\hline
\end{tabular}

Untuk backscater factor diperoleh dengan melakukan interpolasi data dari tabel backscater factor berdasarkan referensi (Bapeten, 2019)(Kramer et al., 2008). Nilai FSD pada AHD Rad mengacu pada data sesuai dengan proyeksi pemeriksaan radiografi yang dilakukan oleh Richard Kramer dkk pada saat penelitian software CALDose_X versi 5.0 (Priyastama, 2017)(Meghzifene et al., 2010). Data pada perhitungan dosis radiasi dilakukan untuk jenis pemeriksaan radiologi dapat dilihat pada tabel 1.

Analisa data dilakukan perbandingan aplikasi AHD Rad dengan aplikasi komputer CALDose_X versi 5.0 sebagai salah satu software yang telah diakui sebagai software dalam pengukuran dosis radiasi, untuk mengetahui nilai signifikan kedua aplikasi perhitungan dosis radiasi tersebut. Pengolahan data menggunakan program SPSS 16 . Pengolahan data diawali dengan melakukan normalisasi data dengan Interpretasi Hasil Uji Normalitas Kolmogorov-Smirnov, untuk melihat apakah data sampel yang digunakan berdistribusi normal. Selanjutnya data yang berdistribusi normal dilakukan uji T Score (Uji Perbandingan Independent Sampel Test), dengan hipotesa penelitian.

$\mathrm{HO}$ : Tidak ada perbedaan signifikan hasil dosis radiasi pada perhitungan menggunakan CALDose_ $X$ versi 5.0 dengan AHD Rad Web Versi 1.0. Syarat Jika nilai sig.( 2-tailed)> 0,05 maka $\mathrm{HO}$ diterima dan $\mathrm{Ha}$ ditolak, yang berarti tidak ada perbedaan signifikan.

$\mathrm{Ha}$ : Ada perbedaan signifikan hasil dosis radiasi pada perhitungan menggunakan CALDose_X versi 5.0 dengan AHD Rad. Syarat jika nilai sig. (2 tailed)< 0.05 maka $\mathrm{HO}$ ditolak dan $\mathrm{Ha}$ diterima, yang berarti ada perbedaan signifikan.

\section{HASIL DAN PEMBAHASAN}

Pengembangan aplikasi perhitungan dosis radiasi pasien dilakukan dengan membangun aplikasi AHD Rad yang diintegrasikan dengan data base pasien di RST dr Soedjono Magelang. Penelitian mengikutsertakan tenaga IT yang bekerja di RST untuk mengembangkan interface AHD Rad dengan program PHP dengan memasukan data base dan rumus perhitungan estimasi dosis radiasi.

Hasil interface dimulai dari menu login untuk masuk kedalam sistem, fitur tampilan pada aplikasi AHD Rad yang telah dibuat dapat dilihat pada Gambar 1. 

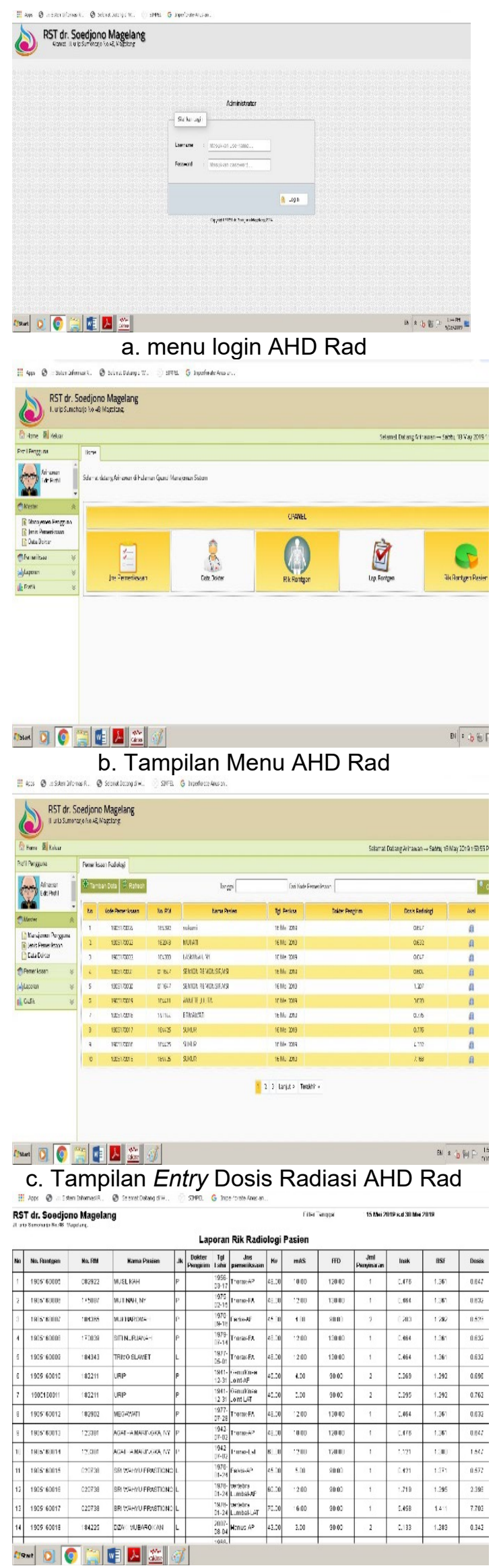

d. Tampilan Report Radiasi AHDRad

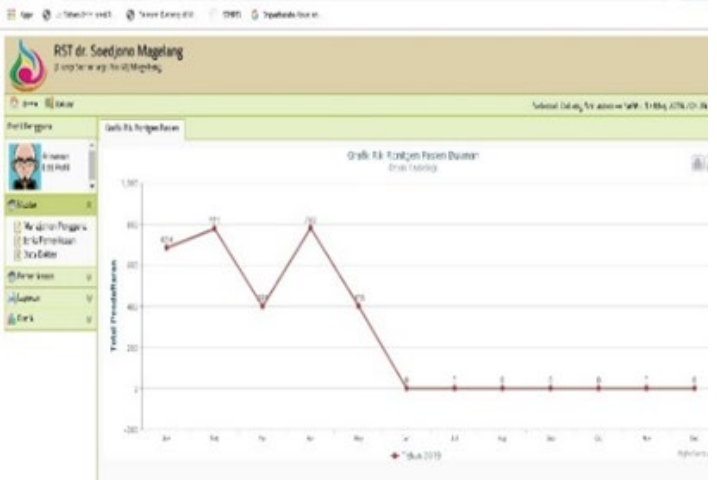

e. Tampilan Grafik AHDRad Versi

Gambar 1. Fitur Tampilan pada Program Aplikasi AHD Rad

Telah dibuat aplikasi perhitungan dosis permukaan kulit pada pasien pemeriksaan radiologi berbasis web yang di sebut AHD Rad di RST dr.Soedjono Magelang. Penggunaan AHD Rad sama dengan CALDose_X versi 5.0 yaitu dengan menginputkan nilai parameter faktor eksposi berupa tegangan tabung $(\mathrm{kV})$, arus tabung dan waktu eksposi (mAS) serta FFD yang dipergunakan radiografer selama melakukan pemeriksaan pasien. Faktor eksposi inilah yang selanjutnya akan dilakukan perhitungan secara komputerisasi dan selanjutnya menghasilkan nilai dari dosis radiasi permukaan kulit pasien.

Tabel 2. Nilai Uji Normalitas KolmogorovSmirnov Untuk AHD Rad dan CALDose_X versi 5.0

\begin{tabular}{lllc}
\hline \multicolumn{1}{c}{ Kelompok } & \multicolumn{3}{c}{ Kolmogorov-Smirnov } \\
\cline { 2 - 4 } & Statistik & Df & Sig \\
\hline $\begin{array}{l}\text { Data CALDose_X } \\
\text { versi 5.0 }\end{array}$ & 0,84 & 50 & 0,200 \\
$\begin{array}{l}\text { Data } \\
\text { AHDRad_Web }\end{array}$ & 0,83 & 50 & 0,200 \\
\hline
\end{tabular}

Sumber data: output SPSS 16 diolah tahun 2021

Sebelum dilakukan uji $\mathrm{T}$ Score pada kedua data ESAK (dosis radiasi) CALDose_X versi 5.0 dengan AHD Rad, dilakukan terlebih dahulu uji normalisasi dengan menggunakan SPSS metode Kolmogorov-Smirnov dengan tujuan untuk menentukan apakah data dapat dilakukan apakah data dapat dilakukan uji parametrik atau non parametrik. Jika data menunjukkan hasil normal (data parametrik) maka selanjutnya dapat dilakukan uji parametrik dengan uji T Score. 
Tabel 3. Uji Perbandingan t Test Independent Sampel Test CaldoseX-5 dan AHD Rad

\begin{tabular}{|c|c|c|c|c|}
\hline Data & $\mathbf{N}$ & $\begin{array}{l}\text { Levene } \\
\text { Test of } \\
\text { Variensc } \\
\text { e Sig }\end{array}$ & $\begin{array}{l}\text { T } \\
\text { Value }\end{array}$ & $\begin{array}{l}\text { Sign. } \\
\text { (2- } \\
\text { tailed) }\end{array}$ \\
\hline $\begin{array}{l}\text { CALDose } \\
X \text { versi }\end{array}$ & 50 & & & \\
\hline $\begin{array}{l}\overline{5} .0 \\
\text { AHD Rad }\end{array}$ & 50 & 0,454 & 0.171 & 0,865 \\
\hline
\end{tabular}

Pada tabel 2 hasil uji normalitas menunjukkan pada CALDose_X versi 5.0 dengan AHD Rad dengan nilai 0,200. Hasil tersebut menunjukkan signifikan untuk kelompok tersebut $>0.05$, maka sebagaimana dasar pengambilan keputusan dalam uji normalitas Kolmogorov-Smirnov di atas, dapat disimpulkan bahwa data hasil dosis radiasi pasien untuk CALDose $X$ versi 5.0 dan AHD Rad adalah berdistribusi normal.

Hasil pengolahan perbedaan aplikasi CALDose_X versi 5.0 dengan AHD Rad, berdasarkan tabel out put di atas menunjukkan jumlah data dosis radiasi untuk CALDose_ $X$ versi 5.0 adalah sebanyak 50 dilihat dari nilai $\mathrm{N}$. Untuk data AHD Rad juga sebanyak 50. Nilai rata-rata dosis radiasi CALDose_X versi 5.0 adalah sebesar 3.7646 , sedangkan rata-rata untuk AHD Rad adalah 3,6829. Secara deskriptif tidak banyak perbedaan nilai rata-rata pada hasil dosis radiasi penggunaan CALDose_X versi 5.0 dengan AHD Rad. Untuk membuktikan apakah hasil deskriptif (tidak ada perbedaan) tidak signifikan (nyata) maka perlu diperhatikan output pada tabel output independent samples test pada colom Sig.(2tailed).

Berdasarkan output data, diketahui nilai sig Levene's Test for Equality of Variances adalah sebesar 0,454 . Sehingga nilai $0,454>0.05$ maka dapat diartikan bahwa varians data antara dosis radiasi CALDose_X versi 5.0 dengan AHD Rad adalah homogen atau sama (Kramer et al., 2008).

Selanjutnya berdasarkan tabel 3 output "Independence Samples Test" pada bagian " Equal variances assumed" diketahui nilai Sig.(2-tailed) sebesar 0,865 > 0.05, maka sebagaimana dasar pengambilan keputusan dalam uji independent sampel $t$ test dapat disimpulkan $\mathrm{HO}$ diterima dan Ha ditolak (Kramer et al., 2008). Sehingga dapat disimpulkan bahwa tidak ada perbedaan yang signifikan (nyata) antara hasil dosis radiasi pada penggunaan CALDose_X versi 5.0 dengan AHD Rad.

\section{SIMPULAN DAN SARAN}

Telah berhasil dibuat aplikasi berbasis web yaitu AHD Rad untuk menghitung dosis permukaan pasien pada pemeriksaan radiologi Berdasarkan analisa SPSS memberikan keyakinan dengan tingkat kepercayaan $95 \%$ margin eror $5 \%$, bahwa hasil perhitungan dosis radiasi pada aplikasi AHD Rad siginifikan dengan CALDose_X versi 5.0 sehingga dapat dipergunakan untuk melakukan dosimetri pada pemeriksaan radiologi umum.

\section{UCAPAN TERIMAKASIH}

Terima kasih kami sampaikan kepada bapak Muhammad Purwanto, S.Kom sebagai tim IT yang telah turut mengembangkan sistem AHD Rad, serta radiografer instalasi radiologi RST dr Soedjono Magelang yang telah berkontribusi dalam penelitian ini.

\section{DAFTAR RUJUKAN}

Bapeten. (2019). Pedoman Teknis Penyusunan Tingkat Panduan Diagnostik Atau Diagnostic Reference Level (DRL) Nasional. Pusat Pengkajian Sistem Dan Teknologi Pengawasan Fasilitas Radiasi Dan Zat Radioaktif Badan Pengawas Tenaga Nuklir.

Dianasari, T., \& Koesyanto, H. (2017). PENERAPAN MANAJEMEN KESELAMATAN RADIASI DI INSTALASI RADIOLOGI RUMAH SAKIT. Unnes Journal of Public Health. https://doi.org/10.15294/ujph.v6i3.12690

International Atomic Energy Agency. (2007). Technical Reports Series No. 457 Dosimetry in diagnostic radiology: an internacional code of practice. IAEA.

Jones, J. G. A., Mills, C. N., Mogensen, M. A., \& Lee, C. I. (2012). Radiation dose from medical imaging: A primer for emergency physicians. In Western Journal of Emergency Medicine. https://doi.org/10.5811/westjem.2011.11. 6804

KARS. (2017). Standar Nasional Akreditasi Rumah Sakit Edisi 1. Komisi Akreditasi Rumah Sakit.

Kim, S., Toncheva, G., Anderson-Evans, C., Huh, B. K., Gray, L., \& Yoshizumi, T. (2009). Kerma area product method for effective dose estimation during lumbar epidural steroid injection procedures: Phantom study. American Journal of Roentgenology. https://doi.org/10.2214/AJR.08.1713

Kramer, R., Khoury, H. J., \& Vieira, J. W. (2008). CALDose_X - A software tool for the assessment of organ and tissue absorbed doses, effective dose and cancer risks in 
diagnostic radiology. Physics in Medicine e-ISSN : 2614-7017 and Biology. https://doi.org/10.1088/00319155/53/22/011

Meghzifene, A., Dance, D. R., McLean, D., \& Kramer, H. M. (2010). Dosimetry in diagnostic radiology. European Journal of Radiology.

https://doi.org/10.1016/j.ejrad.2010.06.03 2

Petoussi-Henss, N., Zankl, M., Drexler, G., Panzer, W., \& Regulla, D. (1998). Calculation of backscatter factors for diagnostic radiology using Monte Carlo methods. Physics in Medicine and Biology. https://doi.org/10.1088/00319155/43/8/017

Priyastama, R. (2017). SPSS Pengolahan Data dan Analisis Data. Start UP.

Undang-Undang No. 33 Tahun 2007 Tentang Keselamatan Radiasi pengion dan Keamanan Sumber Radioaktif, (2007). 